\title{
Moss diversity in the state of Aguascalientes, Mexico: Revision and update
}

\section{@creative}

Botanical Sciences

95 (3): 503-513, 2017

DOI: 10.17129/botsci.891

Copyright: $@ 2017$ Delgadillo-Moya \& Peña-Retes. This is an open access article distributed under the terms of the Creative Commons Attribution License, which permits unrestricted use, distribution, and reproduction in any medium, provided the original author and source are credited.

\section{Claudio Delgadillo-Moya* and Ana Paola Peña-Retes}

\section{Abstract}

Background: Seven moss species were known from the state of Aguascalientes before a study by Delgadillo et al. (2015) listed 38 new records for its moss flora.

Hypothesis: Despite its comparatively dry climate, Aguascalientes could harbor a more diverse moss flora. Geographically, this would be an extension of the moss flora of Jalisco and Zacatecas.

Study site and dates: Moss collections in Aguascalientes were made in August 2014 and September 2015, with emphasis on northwestern and southwestern localities.

Methods: About 165 moss samples were collected in old fields, streambeds, and areas covered with chaparral vegetation. These and 140 herbarium specimens from the herbarium of Universidad Autónoma de Aguascalientes (HUAA) were studied to prepare the species list.

Results: The Aguascalientes moss flora comprises at least 95 moss species and varieties, including 50 new state records. The families Pottiaceae (34 species), Bryaceae (11) and Grimmiaceae (7) are the most important. It is a flora characteristic of the drylands, but with some highland representatives. Keys for the identification of the known moss species are included.

Conclusions: A larger species number should be expected once less-accessible areas are explored. The known Aguascalientes moss flora is characteristic of dry land areas extending to Jalisco and Zacatecas, but with some high elevation species. It comprises cleistocarpic taxa and other with peculiar adaptations. Some species form associations that require other forms of analysis.

Key words: Bryophyte, mosses, species richness, Mexico.

\section{Diversidad de musgos en el estado de Aguascalientes, México: Revisión y actuali- zación.}

Resumen

Antecedentes: Se conocían siete especies de musgos para Aguascalientes hasta que Delgadillo et al. (2015) registraron 38 especies y variedades nuevas para la flora de ese estado.

Hipótesis: Aunque ocupa áreas geográficas comparativamente secas, Aguascalientes debe tener una flora más diversa. Ésta podría ser una extensión de la flora de musgos de Jalisco y Zacatecas.

Sitio de estudio y fechas: En Agosto de 2014 y Septiembre de 2015 se visitó el estado de Aguascalientes, con énfasis en localidades del noroeste y suroeste.

Métodos: Se colectaron 165 muestras de musgos en campos abandonados, lechos de arroyo y matorrales. Además, se estudiaron 140 ejemplares del herbario de la Universidad Autónoma de Aguascalientes (HUAA) para preparar el listado de especies.

Resultados: La flora contiene 95 especies de musgos, 50 de las cuales son registros nuevos para Aguascalientes. Los miembros de las familias Pottiaceae, con 34 especies, Bryaceae (11) y Grimmiaceae (7) son las más importantes. Se incluyen claves para la determinación de las especies conocidas.

Conclusiones: Se debe esperar un número mayor de especies con la exploración de áreas de difícil acceso. La flora de musgos de Aguascalientes es característica de las zonas secas que incluyen a Jalisco y Zacatecas, pero con representantes de zonas altas. Contiene taxa cleistocárpicos y otros con adaptaciones peculiares. Algunas especies forman asociaciones que requieren otras formas de análisis.

Palabras clave: Bryophyta, musgos, riqueza de especies, México. 
preliminary contribution (Delgadillo et al. 2015) noted that several states in central Mexico were poorly explored and their moss floras were not well known. Guanajuato, Querétaro, and Zacatecas received some recent attention, but Aguascalientes remained unexplored until 2013. Collections reported by Delgadillo et al. (2015) listed the names of 45 moss species and varieties, including seven previously known for the flora of Aguascalientes; collecting effort and niche modelling analysis suggested a potential richness of 91 species for the state when a broader exploration were conducted. The earlier report also proposed that this moss flora was an extension of the dry land flora of Jalisco and Zacatecas, but no further comment was offered because of the limited floristic information available. With no other publications on the subject, additional field work was conducted to gain insight on the size and diversity of the state moss flora. This contribution updates the previous list, re-examines the distribution of the species, and provides a key for the identification of known species in Aguascalientes.

\section{Materials and methods}

In August 2014 and September 2015, the authors collected about 165 moss specimens, mainly in north- and southwestern localities in Aguascalientes (Table 1, Figure 1). Abandoned fields

Figure 1. Collecting localities in Aguascalientes. Localities reported by Delgadillo et al. (2015) are indicated by diamonds. Solid circles represent recent collections by the authors and by HUAA personnel.

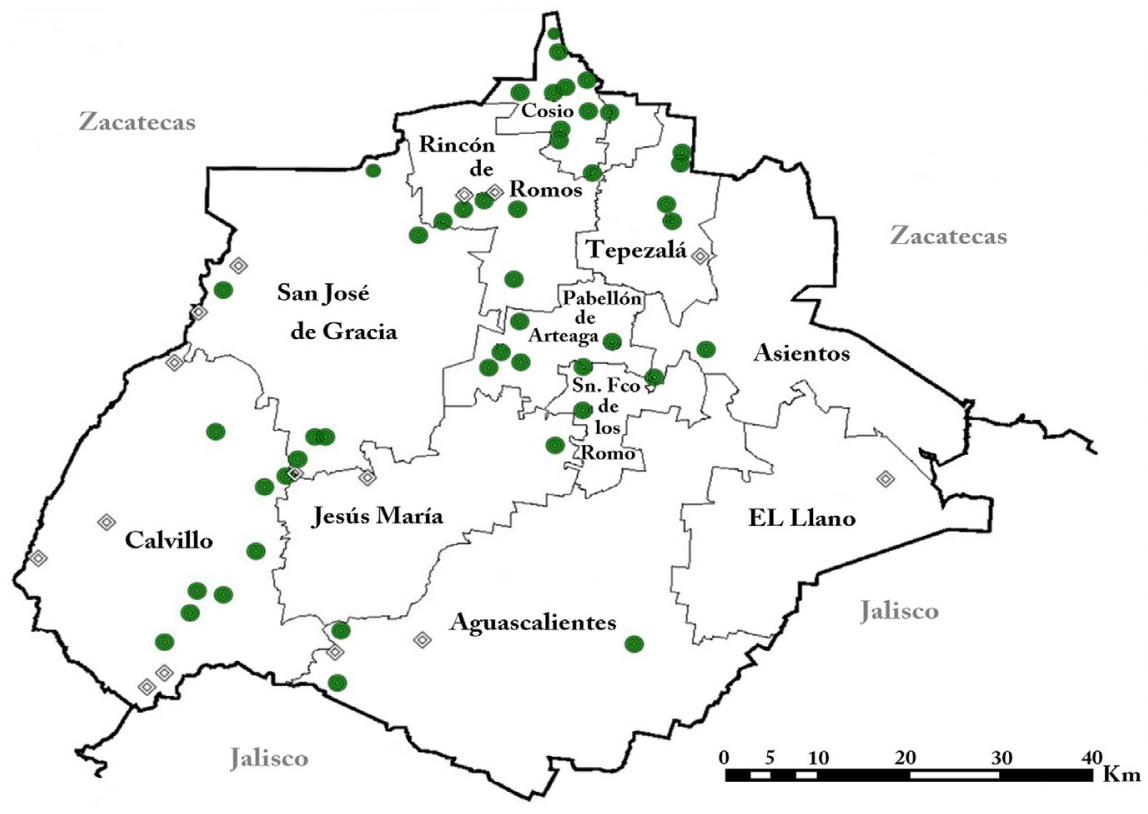

Table 1. Moss collecting sites in Aguascalientes in 2014, 2015. Specimen numbers preceded by PP were collected by Paola Peña. Four-digit numbers belong to collections by C. Delgadillo.

\begin{tabular}{llll}
\hline Specimen Number & Localities & Coordinates (N - W) & Elev. (m) \\
\hline PP 297-305; 7704-7720 & Cerro El Salteador & $21^{\circ} 44^{\prime} 37^{\prime \prime}-102^{\circ} 31^{\prime} 34^{\prime \prime}$ & $1950-2000$ \\
$7675-7677$ & San Antonio Montoya & $21^{\circ} 56^{\prime} 32^{\prime \prime}-102^{\circ} 04^{\prime} 00^{\prime \prime}$ & 2040 \\
$7678-7683$ & Cerca de Ojo de Agua & $22^{\circ} 01^{\prime} 29^{\prime \prime}-101^{\circ} 56^{\prime} 35^{\prime \prime}$ & 2000 \\
7684 & Cerca de Charco Azul & $22^{\circ} 02^{\prime} 56^{\prime \prime}-102^{\circ} 01^{\prime} 36^{\prime \prime}$ & 1950 \\
PP 321-323; 7744-7747 & 17 km W La Congoja & $22^{\circ} 09^{\prime} 8^{\prime \prime}-102^{\circ} 39^{\prime} 32^{\prime \prime}$ & 2520 \\
PP 306-320; 7734-7743 & 10 km S La Congoja & $22^{\circ} 11^{\prime} 31^{\prime \prime}-102^{\circ} 38^{\prime} 15^{\prime \prime}$ & 2580 \\
PP 324-327; 7748-7754 & 10 km NW San José de Gracia & $22^{\circ} 09^{\prime} 36^{\prime \prime}-102^{\circ} 22^{\prime} 16^{\prime \prime}$ & 2290 \\
$7694-7695$ & San Gil & $22^{\circ} 11^{\prime} 51^{\prime \prime}-102^{\circ} 01^{\prime} 16^{\prime \prime}$ & 2030 \\
PP 328-336; 7755-7769 & Boca del Túnel de Potrerillo & $22^{\circ} 13^{\prime} 48^{\prime \prime}-102^{\circ} 26^{\prime} 49^{\prime \prime}$ & 2020 \\
PP 288; 7693 & Tepezala & $22^{\circ} 13^{\prime} 22^{\prime \prime}-102^{\circ} 11^{\prime} 08^{\prime \prime}$ & 1980 \\
PP 289-291; 7696 & Cerca de La Boquilla & $22^{\circ} 15^{\prime} 32^{\prime \prime}-102^{\circ} 22^{\prime} 48^{\prime \prime}$ & 1960 \\
PP 292-293; 7697 & Cerca de La Boquilla. & $22^{\circ} 14^{\prime} 59^{\prime \prime}-102^{\circ} 23^{\prime} 49^{\prime \prime}$ & 2010 \\
PP 294-295; 7698-7703 & Cerca de La Boquilla & $22^{\circ} 15^{\prime} 01^{\prime}-102^{\circ} 24^{\prime} 16^{\prime \prime}$ & 2080 \\
PP 284-287; 7685-7692 & Las Pilas & $22^{\circ} 15^{\prime} 15^{\prime \prime}-102^{\circ} 10^{\prime} 40^{\prime \prime}$ & 2000
\end{tabular}


(San Antonio Montoya), riparian vegetation or stream beads (Ojo de Agua, Charco Azul), and scrubland vegetation elsewhere were the source of our collections. In addition, 140 miscellaneous specimens from the herbarium of Universidad Autónoma de Aguascalientes (HUAA), served to update the floristic list for that state. All specimens were identified and deposited in the Bryophyte Collection of the National Herbarium (MEXU), with duplicates for HUAA and other herbaria.

\section{Results}

The list of taxa in Table 2 contains 50 new records for the moss flora of Aguascalientes. These are unmarked under "A" to distinguish them from previously reported records (Delgadillo et al. 2015), and bring the total number to 95 taxa, i.e., four species above the previously estimated number. Most of the species are also known from Jalisco or Zacatecas so that the Aguascalientes moss flora may indeed represent an extension of the flora from those states (Delgadillo et al. 2015).

The moss flora of Aguascalientes contains numerous taxa from dry land areas. Among them, the Pottiaceae are rather frequent, with 34 species and varieties for a $36 \%$ of the total state moss flora. The Bryaceae, with 11 species, only make a $12 \%$. The Grimmiaceae, with seven species (ca. $7 \%$ of the total), are also noteworthy because they are rock inhabitants and more diverse than fifteen other families that are represented by five or less in the state moss flora. At the generic level mosses are represented by 43 genera, or nearly $13 \%$ of the Mexican moss flora.

The list contains such taxa as Anomobryum conicum that seem rare or may be infrequently collected while others such as Aloina hamulus and Didymodon spp., are rather frequent in the region. The flora also includes a significant number of high elevation taxa that are known to occur in Jalisco or in the alpine regions of central Mexico; Aongstroemia orientalis and species of Grimmia are in this group. Most species live on soil or rocks. The number of epiphytes is comparatively small (14 species, Table 2) because, in addition to low rainfall, tree cover is sparse and may offer scarce protection against desiccation. Species of Fabronia, Leskea, Lindbergia, and Orthotrichum usually occupy these habitats.

Hennediella stanfordensis, only known from the state of Guerrero, is represented by two poorly preserved specimens from San Francisco de los Romo area, but the identification is facilitated by a differentiated papillose leaf margin with thick-walled elongated cells, and a mucro standing against an entire leaf apex. Jaffueliobryum arsenei and Ptychomitrium chimborazense have narrow ranges; the former is known from Zacatecas to Querétaro, but in Aguascalientes it seems more frequent although it is officially recognized as rare (Delgadillo 1996). The distribution of the latter in Mexico extends from Zacatecas to Puebla, but collections have been occasional, only. Archidium donnellii, Pleuridium mexicanum, and Tortula acaulon are the only cleistocarpic mosses known for this state. Anomobryum plicatum and Entosthodon obtusatus are tentatively included in the list because specimen identification was uncertain due to immature or sterile material available. There are no species restricted to Aguascalientes, but its flora includes Grimmia involucrata, G. pulla, Hennediella heteroloma, Jaffueliobryum arsenei, and Trichostomum subangustifolium, endemic to Mexico.

Although most species are cited in Sharp et al.(1994), the keys introduced in this contribution reflect recent taxonomic and nomenclatural arrangements. They should facilitate the identification of mosses from Aguascalientes. For this purpose, observations in the following paragraph are to be considered.

Moss keys usually distinguish the erect from the prostrate habit. Such growth forms may be labeled as "acrocarpous" and "pleurocarpous", as defined in standard floras and glossaries, but they have been omitted in the keys to avoid confusion. Broadly speaking, such terms describe the position of the perichaetium in a branching system. In the acrocarpous mosses, a single perichaetium is formed at the end of a primary module of a branch system; in the pleurocarpous mosses one or more perichaetia are produced per primary or secondary module, at the end of lateral innovations that lack branch primordia or developed branches. A third moss growth type that is seldom mentioned is termed "cladocarpous" where the primary modules end in vegetative growth and the perichaetia are produced at the end of lateral branches of secondary or tertiary branches (La Farge-England 1996). Withey (1996) suggests that the cladocarpous condition is 
Table 2. Mosses from the state of Aguascalientes. A, species previously recorded by Delgadillo et al. (2015); those without a mark are new state records. The records for Jal (Jalisco) and Zac (Zacatecas) were cited by Sharp et al. (1994) or come from specimens at MEXU (H). Sb = substrate: R, rock; S, soil; Sr, soil-covered rocks; T, trunk; r, root

\begin{tabular}{ll} 
A & TAXA \\
\hline$X$ & Aloina hamulus (Müll. Hal.) Broth.
\end{tabular}

Anacolia laevisphaera (Taylor) Flowers

Anoectangium aestivum (Hedw.) Mitt.

Anomobryum conicum (Hornsch.) Broth.

X Anomobryum julaceum (Gaertn., Meyer \& Schreb.) Schimp. Anomobryum plicatum Cardot Aongstroemia orientalis Mitt.

Archidium donnellii Austin

X Barbula orizabensis Müll. Hal.

X Brachymenium mexicanum Mont.

X Brachymenium systylium (Müll. Hal.) A. Jaeger

Brachythecium frigidum (Müll. Hal.) Besch.

Brachythecium ruderale (Bird.) W. R. Buck

X Braunia andrieuxii Lorentz

Braunia plicata (Mitt.) A. Jaeger

X Braunia secunda (Hook.) Bruch \& Schimp.

Bryoerythrophyllum inaequalifolium (Taylor) R. H. Zander

Bryoerythrophyllum recurvirostrum (Hedw.) Chen var. recurvirostrum

Bryoerythrophyllum recurvirostrum var. aeneum (Müll. Hal.)

\begin{tabular}{|c|c|c|c|}
\hline Jal & Zac & $\mathbf{H}$ & $\mathrm{Sb}$ \\
\hline$x$ & $x$ & $*$ & $\mathrm{~S} S, \mathrm{Sr}$ \\
\hline$x$ & $x$ & $*$ & S \\
\hline \multirow[t]{2}{*}{$x$} & $x$ & $*$ & S \\
\hline & & & $R$ \\
\hline$x$ & $x$ & $*$ & S \\
\hline$x$ & & $*$ & S \\
\hline \multirow[t]{2}{*}{$x$} & & & S \\
\hline & $x$ & $*$ & S \\
\hline$x$ & & & S \\
\hline$x$ & $x$ & $*$ & $\mathrm{R}, \mathrm{S}, \mathrm{Sr}$ \\
\hline \multirow[t]{2}{*}{$x$} & & & $\mathrm{~T}$ \\
\hline & & & $\mathrm{Sr}$ \\
\hline$x$ & & & $\mathrm{Sr}$ \\
\hline \multirow[t]{2}{*}{$x$} & $x$ & $*$ & $\mathrm{R}, \mathrm{S}, \mathrm{Sr}$ \\
\hline & & & $\mathrm{T}$ \\
\hline$x$ & $x$ & $*$ & $\mathrm{R}$ \\
\hline$x$ & $x$ & $*$ & $S$ \\
\hline \multirow[t]{2}{*}{$x$} & & $*$ & S \\
\hline & $x$ & & S \\
\hline$x$ & $x$ & $*$ & S \\
\hline$x$ & $x$ & $*$ & S \\
\hline \multirow[t]{3}{*}{$x$} & $x$ & $*$ & $\mathrm{~S}, \mathrm{Sr}$ \\
\hline & & & $\mathrm{S}$ \\
\hline & & & $\mathrm{S}$ \\
\hline$x$ & & & $S$ \\
\hline$x$ & & & S \\
\hline$x$ & $x$ & $*$ & $\mathrm{R}, \mathrm{Sr}$ \\
\hline \multirow[t]{2}{*}{$x$} & & & $S$ \\
\hline & $x$ & $*$ & $\mathrm{Sr}$ \\
\hline$x$ & $x$ & $*$ & $R, S$ \\
\hline$x$ & $x$ & & $\mathrm{~S}$ \\
\hline$x$ & $x$ & $*$ & $S$ \\
\hline$x$ & $x$ & $*$ & S \\
\hline$x$ & $x$ & $*$ & $\mathrm{~S}, \mathrm{Sr}$ \\
\hline \multirow[t]{4}{*}{$x$} & $x$ & $*$ & $R$ \\
\hline & $x$ & $*$ & S \\
\hline & & & S \\
\hline & & & $S$ \\
\hline$x$ & & $*$ & $S$ \\
\hline$x$ & & $*$ & S \\
\hline$x$ & & & $\mathrm{~T}$ \\
\hline$x$ & & $*$ & $R$ \\
\hline$x$ & $x$ & $*$ & $\mathrm{~T}$ \\
\hline$x$ & & & $\mathrm{~T}$ \\
\hline \multirow[t]{2}{*}{$x$} & $x$ & $*$ & $\mathrm{~T}$ \\
\hline & $x$ & $*$ & $\mathrm{~T}$ \\
\hline$x$ & $x$ & $*$ & $\mathrm{Sr}$ \\
\hline$x$ & $x$ & & $\begin{array}{c}\mathrm{S}, \mathrm{Sr} \\
\mathrm{Sr}\end{array}$ \\
\hline
\end{tabular}

$$
\text { R. H. Zander }
$$

X Bryum argenteum Hedw.

$X$ Bryum billarderi Schwägr.

X Bryum chryseum Mitt.

Bryum coronatum Schwägr.

X Campyliadelphus chrysophyllus (Brid.) Kanda Campylopus albidovirens Herz.

Campylopus flexuosus (Hedw.) Brid.

X Campylopus pilifer Brid.

X Ceratodon purpureus(Hedw.) Brid. subsp. stenocarpus (Bruch \& Schimp.) Dixon

X Crossidium crassinervia (De Not.) Jur.

X Didymodon australasiae (Hook. \& Grev.) R.H. Zander

X Didymodon revolutus (Cardot) R.S. Williams

$X$ Didymodon rigidulus var. gracilis (Schleich. Ex Hook. \& Grev.) R.H. Zander

X Didymodon rigidulus var. icmadophilus (Schimp. ex Müll. Hal.) R.H. Zander

$\mathrm{X}$ Didymodon rigidulus var. rigidulus

Entodon beyrichii (Schwägr.) Müll. Hal.

X Entosthodon apiculatopilosus (Cardot) Fife Entosthodon jamesonii (Taylor) Mitt.

Entosthodon obtusatus (Schimp.) Fife

Entosthodon obtusifolius Hook. f.

Epipterygium immarginatum Mitt.

$X \quad$ Eythrodontium longisetum (Hook.) Paris

$X$ Eythrodontium squarrosum (Hampe) Paris Fabronia ciliaris var. ciliaris

X Fabronia ciliaris var. polycarpa(Hook.) W.R. Buck Fabronia ciliaris var. wrightii (Sull.) W.R. Buck

X Fabronia macroblepharis Schwägr.

X Fissidens bryoides Hedw.

X Fissidens crispus Mont.

Fissidens elegans Brid. 
Table 2. Continuation.

\begin{tabular}{|c|c|c|c|c|c|}
\hline A & TAXA & Jal & Zac & $\mathbf{H}$ & Sb \\
\hline $\bar{x}$ & Fissidens guianensis Mont. & $x$ & & & $\mathrm{~S}$ \\
\hline \multirow[t]{4}{*}{$x$} & Fissidens sublimbatus Grout & & & & $\mathrm{S}$ \\
\hline & Funaria hygrometrica var. calvescens (Schwägr.) Mont. & $x$ & $x$ & $*$ & $\mathrm{~S}$ \\
\hline & Funaria hygrometrica var. hygrometrica & $x$ & $x$ & $*$ & $\mathrm{~S}$ \\
\hline & Globulinella globifera (Hampe) Steere & $x$ & & & $\mathrm{~S}$ \\
\hline \multirow[t]{2}{*}{$\mathrm{X}$} & Grimmia elongata Kaulf. & $x$ & & & $\mathrm{R}$ \\
\hline & Grimmia involucrata Cardot & & $x$ & $*$ & $\mathrm{R}$ \\
\hline $\mathrm{X}$ & Grimmia laevigata (Brid.) Brid. & & $x$ & & $\mathrm{R}$ \\
\hline$x$ & Grimmia longirostris Hook. & $x$ & $x$ & $*$ & $\mathrm{R}, \mathrm{Sr}$ \\
\hline$x$ & Grimmia ovalis (Hedw.) Lindb. & & $x$ & $*$ & $\mathrm{R}$ \\
\hline \multirow[t]{3}{*}{$\mathrm{X}$} & Grimmia pulla Cardot & $x$ & & & $\mathrm{R}, \mathrm{Sr}$ \\
\hline & Gymnostomum aeruginosum Sm. & $x$ & & $*$ & $\mathrm{Sr}$ \\
\hline & Haplocladium microphyllum (Hedw.) Broth. & $x$ & & $*$ & $\mathrm{R}$ \\
\hline \multirow[t]{3}{*}{$x$} & Hennediella heteroloma (Cardot) R.H. Zander & $x$ & $x$ & $*$ & $\mathrm{r}$ \\
\hline & Hennediella stanfordensis (Steere) Blockeel & & & & $\mathrm{R}$ \\
\hline & Hyophila involuta (Hook.) A. Jaeger & $x$ & $x$ & $*$ & $\mathrm{R}$ \\
\hline$x$ & Jaffueliobryum arsenei (Thér.) Thér. & & $x$ & $*$ & $\mathrm{R}$ \\
\hline$x$ & Leptodontium flexifolium (Dicks..) Hampe & $x$ & $x$ & $*$ & $\mathrm{~S}$ \\
\hline \multirow[t]{6}{*}{$x$} & Leskea angustata Taylor & $x$ & $x$ & $*$ & $\mathrm{~T}$ \\
\hline & Lindbergia mexicana (Besch.) Cardot & & $x$ & $*$ & $\mathrm{~T}$ \\
\hline & Orthotrichum bartramii R.S. Williams & & & & $\mathrm{T}$ \\
\hline & Orthotrichum diaphanum Schrad. ex Brid. & & $x$ & $*$ & $\mathrm{~T}$ \\
\hline & Orthotrichum pycnophyllum Schimp. & $x$ & $x$ & * & $\mathrm{T}$ \\
\hline & Plaubelia sprengelii var. stomatodonta (Cardot) R.H. Zander & $x$ & $x$ & * & $\mathrm{S}$ \\
\hline$x$ & Pleuridium mexicanum Cardot & & $x$ & * & $\mathrm{S}$ \\
\hline$x$ & Pogonatum campylocarpon (Müll. Hal.) Mitt. & $x$ & $x$ & $*$ & $\mathrm{~S}, \mathrm{Sr}$ \\
\hline \multirow[t]{4}{*}{$x$} & Pogonatum oligodus (Kunze ex Müll. Hal) Mitt. & & $x$ & $*$ & $\mathrm{~S}, \mathrm{Sr}$ \\
\hline & Pohlia nutans (Hedw.) Lindb. & & & & $\mathrm{S}$ \\
\hline & Pohlia oerstediana (Müll. Hal.) A.J. Shaw & $x$ & & * & $\mathrm{S}$ \\
\hline & Pseudocrossidium crinitum (Schultz) R.H. Zander & & $x$ & $*$ & $\mathrm{~S}$ \\
\hline \multirow[t]{3}{*}{$x$} & Pseudocrossidium replicatum (Taylor) R.H. Zander & $x$ & $x$ & $*$ & $\mathrm{~S}, \mathrm{Sr}$ \\
\hline & Ptychomitrium chimborazense (Spruce ex Mitt.) A. Jaeger & & $x$ & $*$ & $\mathrm{R}$ \\
\hline & Syntrichia bartramii (Steere) R.H. Zander & & & & $\mathrm{S}$ \\
\hline$x$ & Syntrichia chisosa (Magill, Delgad. \& L. R. Stark) R.H. Zander & & $x$ & $*$ & $\mathrm{R}, \mathrm{S}$ \\
\hline \multirow[t]{4}{*}{$x$} & Syntrichia fragilis (Taylor) Ochyra & $x$ & $x$ & $*$ & $\mathrm{R}, \mathrm{S}, \mathrm{Sr}, \mathrm{T}$ \\
\hline & Syntrichia obtusissima (Müll. Hal) R.H. Zander & & $x$ & * & $\mathrm{Sr}$ \\
\hline & Syntrichia pagorum (Milde) J.J. Amann & & $x$ & $*$ & $\mathrm{~S}, \mathrm{~T}$ \\
\hline & Timmiella anomala (Bruch \& Schimp.) Limpr. & $x$ & $x$ & $*$ & $\mathrm{~S}$ \\
\hline$x$ & Tortula acaulon (With.) R.H. Zander & & $x$ & $*$ & $\mathrm{~S}$ \\
\hline \multirow[t]{7}{*}{$x$} & Tortula atrovirens (Sm.) Lindb. & & $x$ & * & $\mathrm{S}$ \\
\hline & Tortula brevipes (Lesq.) Broth. & & & & $\mathrm{R}$ \\
\hline & Trichostomum brachydontium Bruch & $x$ & $x$ & * & $\mathrm{S}$ \\
\hline & Trichostomum crispulum Bruch & & $x$ & $*$ & $\mathrm{~S}$ \\
\hline & Trichostomum subangustifolium (Thér.) R.H. Zander & & & & $\mathrm{S}$ \\
\hline & Weissia controversa Hedw. & $x$ & $x$ & $*$ & $\mathrm{~S}$ \\
\hline & Weissia ligulaefolia (E.B. Bartram) Grout & & & & $\mathrm{S}$ \\
\hline
\end{tabular}

a special form of pleurocarpy. In Aguascalientes, the species of Braunia may be considered as acrocarpous while Anoectangium aestivum is cladocarpous. However, because of their prostrate or erect condition, they have been termed pleurocarpous and acrocarpous, respectively, in standard taxonomic or floristic manuals.

\section{Discussion}

The Aguascalientes floristic list might contain a larger number of species for various reasons. There are many field sites that require exploration, but are privately owned and are not readily 
accessible. On the other hand, farmland, cattle ranches, and industrial facilities are common and represent heavily disturbed areas whose value in moss diversity studies is virtually nil. Frequent disturbance favors the arrival of tolerant species such as Bryum argenteum, B. chryseum or Funaria hygrometrica while many other species are displaced from their original substrates. Despite the need for additional exploration, because the predicted number of species is essentially the same as the number of taxa recovered in our sampling, we conclude that species richness for the state has been conveniently evaluated.

With a land surface area of about 5,471 km² (García de Miranda \& Falcón de Gyves 1984), Aguascalientes is one of the smallest states in Mexico. In spite its small size, its moss flora holds species or groups of species with peculiar features. There is a group of species that occupies disturbed areas whose frequency varies in response to human activities, as mentioned above. In this regard, the eastern and central portions of the state harbor cities, industry, highways, farm and cattle ranges that reduce or modify species dynamics depending on soil management practices. Group composition may vary with the geography, climate, and vegetation of the state; the northern areas are dominated by the dry land species while the western elevations incorporate highland taxa. Detailed mapping and phytosociological evaluations are required in this and neighboring states to detect associations. One such association may be represented by mosses growing on limestone or soils derived from calcareous rocks. Aloina hamulus, Didymodon revolutus, Globulinella globifera, and Pseudocrossidium replicatum are frequently found together in the same areas so that by finding one species the presence of others may be predicted. The frequency of sites where these species occur perhaps reflect the extent of human interference in natural moss communities.

The cleistocarpic species, represented by Archidium donnellii, Pleuridium mexicanum y Tortula acaulon, illustrate the structural and functional diversity of mosses in Aguascalientes. These species may be more frequent in disturbed sites because, in the absence of a dehiscent system, capsules may open by mechanical disturbance by cattle or agricultural equipment. The presence of such species as Jaffueliobryum arsenei marks the existence of other peculiar features in the area. For instance, the monoicous condition termed "cryptoicous" observed in J. arsenei is characterized by the position of both sex organs on the same stem. The perichaetial leaves enclose a small male branch growing from the vaginula, at the base of the sporophyte. The same condition has been described in Ptychomitrium (Deguchi 1977, Deguchi \& Takeda 1986) and Jaffueliobryum (Churchill 1987); both genera are part of the Aguascalientes moss flora.

From the geographical point of view, diversity studies may benefit from the use of environmental indicators. The introductory contribution (Delgadillo et al. 2015) indicated that the potential number of species in the flora would be about 91 moss taxa. Because of the information in this contribution, this may be regarded as a well-known flora. Nevertheless, further exploration elsewhere may confirm or expand knowledge of the distribution of individual taxa and assist in the evaluation of the conservation status of rare or endangered species.

\section{Key to the known moss species in Aguascalientes}

Mosses with prostrate or lateral sporophytes

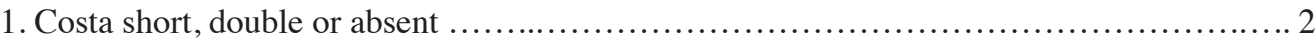

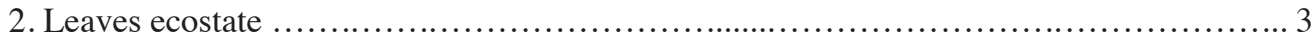

3. Leaf apex with a hyaline hair ........................................... Braunia plicata

3'. Leaf apex not hyaline ..................................................................... 4

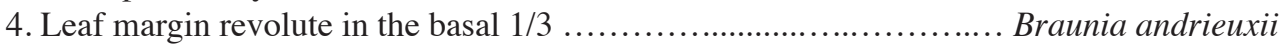

4'. Leaf margin revolute in the basal ? ......................................... Braunia secunda

2'. Costa double, short, usually not extending beyond mid-leaf .......................... 5

5. Leaves not decurrent. Alar cells short, quadrate .............................. Entodon beyrichii

$5^{\prime}$. Leaves with broad decurrencies. Alar cells mainly oblate ................................. 6

6. Leaves oblong-ovate. Seta yellow to orange, exostome smooth

Erythrodontium longisetum

6.' Leaves suborbicular to shortly oblong-ovate. Seta red, exostome striate

Erythrodontium squarrosum 


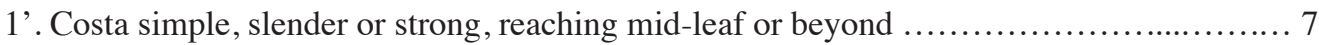

7. Alar cells quadrate, in a small group. Costa ending in an inconspicuous abaxial spine ... 8

8. Leaves with broad decurrencies ................................................... 9

9. Leaves strongly plicate, alar cells inflated; seta papillose ..... Brachythecium frigidum

9'. Leaves weakly plicate or only so at base, alar cells quadrate to rectangular; seta smooth

........................................................................ Brachythecium ruderale

8'. Leaves base rounded, without decurrencies ............... Campyliadelphus chrysophyllus

7'. Alar cells undifferentiated to oblate in a broad proximal region. Costa smooth or rugose... 10

10. Stem and branch leaves differentiated in size and form Paraphyllia smooth

. Haplocladium microphyllum

10'. Stem and branch leaves similar, except in size. Paraphyllia papillose ................... 11

11. Leaf cells inconspicuously papillose .................................................... 12

12. Papillae borne on distal ends of leaf cells. Endostome segments as long as the teeth. Leskea angustata

12'. Papillae borne on cell luminae. Endostome as a fine papillose membrane

11'. Leaf cells smooth

Lindbergia mexicana

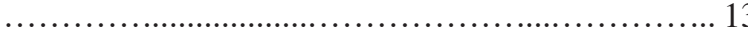

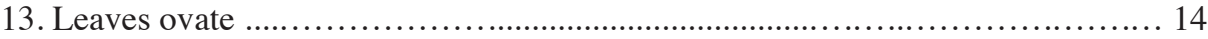

14. Leaves abruptly acuminate, margins entire to long-dentate....

Fabronia ciliaris var. ciliaris

14 '. Leaves gradually acuminate, margins entire to irregularly dentate

Fabronia ciliaris var. polycarpa

13'. Leaves lanceolate to ovate or triangular

15. Leaves lanceolate to oblong-ovate

Fabronia ciliaris var. wrightii 15 '. Leaves oblong-lanceolate to narrowly triangular ......

Fabronia macroblepharis

Mosses with erect stems and apical sporophytes



2. Leaves ovate-lanceolate, with an obtuse apex and excurrent costa .. Anomobryum conicum

2 '. Leaves oblong or oblong-ovate with an obtuse to rounded apex obtuse; costa ending be-

low the apex to subpercurrent

Anomobryum julaceum

$1^{\prime}$. Stems not julaceous, leaves erect, sparse or crowded ....................................... 3

3. Costa excurrent, ending as an awn or hyaline hair ............................................. 4

4. Costa ending as an awn ..................................................................................... 5

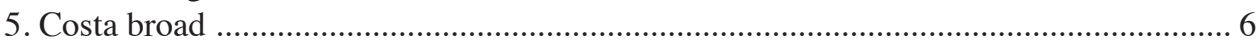

6. Leaf section with hyalocysts and chlorocysts alternating in the abaxial region .............

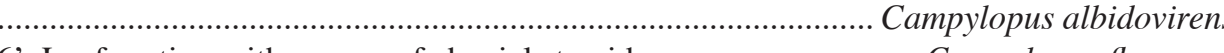

6'. Leaf section with groups of abaxial stereids ............................ Campylopus flexuosus

5'. Costa narrow ............................................................................................. 7

7. Sporophytes cleistocarpous ............................................................................. 8

8. Spores large, more than $100 \mu \mathrm{m}$ in diam ................................. Archidium donnellii

8'. Spores small, less than $50 \mu \mathrm{m}$ in diam .......................................... Tortula acaulon

7'. Sporophytes stegocarpous ............................................................................. 9

9. Leaf margin strongly revolute ....................................... Pseudocrossidium crinitum

9'. Leaf margin plane ..................................................................................... 10

10. Leaves rosulate, at the stem apex, with a strong red awn

.................................................................................. Brachymenium mexicanum

$10^{\prime}$. Leaves not in a rosette, with a fine yellowish awn ...................... Bryum chryseum

4'. Costa ending in a hyaline hair ........................................................................... 11

11. Costa broad, occupying $1 / 2$ to $1 / 3$ of the leaf base ......................... Campylopus pilifer

11 '. Costa narrow ....................................................................................................... 12

12. Distal leaf cells hyaline ......................................................... Bryum argenteum

12 '. Distal leaf cells not hyaline ...............................................................................13 
13. Photosynthetic filaments of costa 2-12 cells long Crossidium crassinervium

13'. Costa without photosynthetic filaments

14. Leaf margin with one to several rows of elongated cells ..... Brachymenium systylium 14'. Marginal leaf cells and inner cells similar

15. Leaf cells in distal half rhomboidal, marginal teeth obtuse-rounded

Entosthodon apiculatopilosus

15 '. Leaf cells in distal half with other shapes, marginal teeth not rounded .............. 16

16. Leaf section with an U- or V-shaped adaxial channel

17. Basal marginal cells uniformly thin-walled

Grimmia elongata

17 '. Transverse walls of marginal basal cells thicker than the longitudinal walls .... 18

18. Leaves unistratose except at margins; costa with two guide cells; seta curved .....

18 '. Leaves distally bistratose, costa with 2-6 guide cells; seta straight

Grimmia pulla

Grimmia longirostris

16'. Leaf section concave, without an obvious adaxial channel

19. Basal leaf cells oblate toward margin

Grimmia laevigata

19'. Basal leaf cells quadrate to short-rectangular ... 20

20. Capsule immersed to emergent

21. Calyptra pilose

21 '. Calyptra smooth ... 21

20'. Capsule exserted Orthotrichum diaphanum Grimmia involucrata

22. Capsule cylindrical, with a spongiose neck 22

22'. Capsule ovoid-cylindrical, with a smooth neck Bryum coronatum

23. Leaves unistratose 23

24. Calyptra mitrate, deeply lobed 24

24 '. Calyptra cucullate 25

25. Leaf apex emarginate, hair point dentate

$25^{\prime}$. Leaf apex obtuse or rounded, hair point not dentate

26. With foliose axillary propagulae

26'. Without specialized propagulae

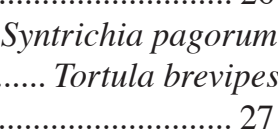

23 '. Leaves partly or wholly bistratose

27. Leaf blade with bistratose patches

27 '. Leaf blade completely bistratose

Jaffueliobryum arsenei

Syntrichia obtusissima

3'. Costa ending below leaf apex or as a mucro
28. Mid-leaf cells thick-walled, vermicular ..........

Syntrichia pagorum
$\ldots$. Tortula brevipes

Syntrichia bartramii Grimmia ovalis 28

(1)

28'. Distal mid-leaf cells thick- or thin-walled, not vermicular .................................. 29

29. Leaves distichous, equitant, with two vaginant laminae ......................................... 30

30. Limbidium present, uni- to tristratose ............................................................ 31

31. Leaf cells strongly bulging, in distinct rows ................................. Fissidens crispus

31 '. Leaf cells slightly or not bulging, not in rows .................................................. 32

32. Leaf cells pluripapillose Fissidens elegans

32'. Leaf cells smooth

33. Limbidium present in all laminae, nearly extending to leaf apex

Fissidens bryoides

33'. Limbidium intramarginal, usually restricted to the vaginant laminae

Fissidens sublimbatus

30'. Limbidium absent

Fissidens guianensis

29'. Leaves in more than two rows, with a single lamina 34

34. Leaves rosulate Bryum billarderi

34'. Leaves distributed along the stem 35

35. Leaves secund, margins erose-denticulate alis

35 '. Leaves not secund, margins entire or dentate 36

36. Leaf cells smooth 37

37. Leaves dimorphous, the lateral larger than the dorsal

Epipterygium immarginatum 
37'. Leaves not dimorphous

38. Leaves with adaxial lamelae 39

39. Lamelae in section ending in a simple square apical cell

39'. Lamelae ending in two flask-shaped cells (geminate)

Pogonatum oligodus Pogonatum campylocarpum

38 '. Leaves without lamelae, sometimes with filaments or cell masses ............... 40

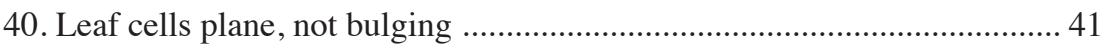



42. Sporophytes cleistocarpous ............................... Pleuridium mexicanum

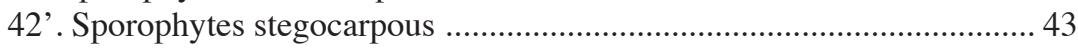

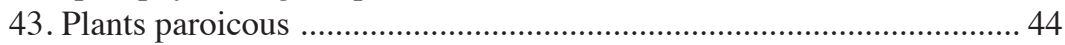

44. Leaves serrate in distal half, cells thick-walled

Pohlia nutans

$44^{\prime}$. Leaves serrate to serrulate near apex, cells thin-walled

Pohlia oerstediana

43'. Plants gonioautoicous or cladautoicous

45. Stomata immersed Orthotrichum bartramii 45'. Stomata superficial Orthotrichum pycnophyllum

41'. Leaves bistratose .. 46 46. Calyptra mitrate ............................ Ptychomitrium chimborazense 46'. Calyptra cucullate ............................................ Timmiella anomala

$40^{\prime}$. Leaf cells mammillose or bulging .... 47 47. Leaves spatulate, with axillary gemmae.............. Hyophila involuta

47'. Leaves with other shapes 48

48. Leaf apex cucullate 49

49. Leaves oblong-ovate, costa slightly spurred

Globulinella globifera

49'. Leaves lingulate, costa and lamina with photosynthetic filaments .. Aloina hamulus

48'. Leaf apex open .50

50. Leaf cells short, quadrate 51

51. Leaves long-lanceolate; capsule erect, smooth

Didymodon rigidulus var. icmadophilus

51'. Leaves lanceolate; capsule inclined, sulcate.

Ceratodon purpureus var. stenocarpus

50 '. Leaf cells irregularly shaped .52

52. Capsule inclined, asymmetric ............................................... 53

53. Capsule curved, inclined to pendent; neck not flattened ........ Funaria hygrometrica var. hygrometrica 53'. Capsule nearly erect to inclined, gradually narrow, with a flat neck ...................... Funaria hygrometrica var. calvescens 52 '. Capsule erect and symmetric

54. Leaves lingulate to spatulate, apex rounded to obtuse, crenulate Entosthodon obtusatus

54'. Leaves oblong to obovate, apex entire 55

55. Leaf apex acute to acuminate Entosthodon jamesonii 55'. Leaf apex rounded-acute Entosthodon obtusifolius

$36^{\prime}$. Leaf cells papillose 56

56. Papillae simple at both cell ends. Anacolia laevisphaera 56'. Papillae variable in number and arrangement in leaf cells

57. Costa with two stereid bands; the adaxial smaller or absent .58

58. Leaf margin strongly involute 59 
59. Leaf cells bulging, with low papillae

Weissia controversa

59. Leaf cells strongly bulging, with columnar papillae..... Weissia ligulaefolia

58. Leaf margin plane, erect or revolute 60

60. Adaxial costal epidermis absent Leptodontium flexifolium

60. Adaxial costal epidermis present 61

61. Adaxial costal epidermis smooth 62

62. Leaf cells papillose on both surfaces Gymnostomum aeruginosum*

62. Leaf cells smooth on the adaxial surface Plaubelia sprengelii var. stomatodonta*

61. Adaxial costal epidermis papillose 63

63. Leaves ligulate to oblong, leaf apex rounded to obtuse .. 64

64. Leaf margin revolute 65

65. Leaf margin revolute nearly to apex; axillary gemmae multicelluar .... Barbula orizabensis $65^{\prime}$. Leaf margin entirely revolute; axillary gemmae unicellu lar ........................... Bryoerythrophyllum inaequalifolium

64'. Leaf margin plane or erect 66

66. Capsule without peristome

Trichostomum subangustifolium

66'. Cepsule with peristome 67

67. Leaf base differentiated, apex cucullate Trichostomum crispulum

67 '. Leaf base not differentiated, apex rounded to acute....... Trichostomum brachydontium

63 '. Leaves oblong-lanceolate to lanceolate, leaf apex acute or rounded 68

68. Leaf apex acute, ending in a sharp hyaline cell

... Bryoerythrophyllum recurvirostrum var. recurvirostrum

68 '. Leaf apex rounded, with several teeth.

Bryoerythrophyllum recurvirostrum var. aeneum

57'. Costa with abaxial stereid band only 69

69. Perichaetium lateral; leaves keeled Anoectangium aestivum

69'. Perichaetium apical; leaves nearly plane .70

70. Basal leaf cells differentiated, hyaline Didymodon australasiae

70'. Basal leaf cells similar to mid-leaf cells 71

71. Costa without hydroids 72

72. Leaves short-ovate, costa spurred

Didymodon revolutus

72'. Leaves long-lanceolate, costa no spurred ........ 73

73. Gemmae frequent; distal leaf margin bistratose Didymodon rigidulus var. rigidulus 73'. Gemmae rare; distal leaf margin occasionally bistratose Didymodon rigidulus var. gracilis

71'. Costa with hydroids .74

74. Leaf margin spirally revolute Pseudocrossidium replicatum

74'. Leaf margin plane or revolute .75 
Received:

August 24th, 2016

Accepted:

December 20th, 2016
75. Costa with a distal cellular pad

Tortula atrovirens

$75^{\prime}$. Costa with 1-2 layers of adaxial over the guide cells 76

76. Leaf border differentiated .......................... 77

77. Intramarginal leaf border unistratose Hennediella heteroloma

$77^{\prime}$. Leaf with a bistratose margin of elongated cells Hennediella stanfordensis

76'. Leaf border not differentiated 78

78. Leaves firm, bistratose, with foliose gemmae Syntrichia chisosa $78^{\prime}$. Leaves fragile, unistratose, without gemmae Syntrichia fragilis

* With one or two stereid bands; the adaxial present or absent

\section{Acknowledgements}

Students and faculty at Universidad Autónoma de Aguascalientes provided field information and a set of moss specimens for study. Special thanks are extended to María Elena Siqueiros, botanist at HUAA for her generous support and herbarium materials. Francisco Juárez López, a visiting student, worked and tested the keys.

\section{Literature cited}

Churchill SP. 1987. Systematics and biogeography of Jaffueliobryum (Grimmiaceae). Memoirs of the New York Botanical Garden 45: 691-708.

Deguchi H. 1977. Small male branches of Ptychomitrium (Grimmiaceae) arised from the base of vaginula inside the perichaetial leaf circle. Miscelanea Bryologica et Lichenologica 7: 177-179.

Deguchi H, Takeda Y. 1986. Reproductive phenology of four species of Ptychomitrium. Proceedings of the Bryological Society of Japan 4: 73-78.

Delgadillo MC. 1996. Moss conservation in Mexico. Proceedings of the International Bryological Conference. Tropical Bryophytes: Biology, Diversity and Conservation. August 7-12, 1995. Mexico City. Anales del Instituto de Biología, Universidad Nacional Autónoma de México, Serie Botánica 67: 177-181.

Delgadillo C, Villaseñor JL, Ortiz E, Peña-Retes AP. 2015. Diversidad de musgos en el estado de Aguascalientes, México. Botanical Sciences 93: 899-906. DOI:10.17129/botsci.206.

García de Miranda E, Falcón de Gyves Z. 1984. Nuevo atlas Porrúa de la República Mexicana. México DF: Editorial Porrúa.

La Farge-England C. 1996. Growth form, branching pattern, and perichaetial position in mosses: Cladocarpy and pleurocarpy redefined. The Bryologist 99: 170-186.

Sharp AJ, Crum H, Eckel PM, eds. 1994. The moss flora of Mexico. Memoirs of the New York Botanical Garden 69: 1-1113.

Withey A. 1996. Phylogenetic studies of the Spiridentaceae (Musci): Observations of three morphological characters associated with pleurocarpy. Anales del Instituto de Biología, Universidad Nacional Autónoma de México, Serie Botánica 67: 5-14. 